\title{
SHAPE-MEMORY MATERIALS AS CONTROL ELEMENTS USED IN DOT BRAILLE ACTUATOR
}

\begin{abstract}
The objective of this paper is to show a designing process for actuators that utilizes shape-memory materials. Analytical studies are carried out to design a dot actuator to be used in an electronic Braille display. Shape-memory materials are a relatively new group of smart materials that exhibit the transformation of their internal structures in solid state phases resulting from external mechanical or thermal excitation. This unique property shows up as three phenomena: one- and two-way memory effects as well as superelasticity, which all significantly influence the change of both the material properties and geometry. Hence, shape-memory materials are used as actuators effectively controlled by the above-mentioned types of excitation.

The work presents the design guidelines for a proposed technical solution as well as the phenomenon utilized in the elaborated model of the actuator. The authors derived the mathematical descriptions for the proposed design configuration and an example of the calculations is shown. Moreover, the characteristics of the elaborated configuration are also discussed, taking into account the range of application areas.
\end{abstract}

Keywords: shape-memory materials, smart materials, actuator, Braille display, design configurations, analytical methods

\section{MATERIAEY Z PAMIECLA KSZTAETU JAKO CZEONY WYKONAWCZE $W$ SIEOWNIKU BRAILLE'A}

$W$ artykule przedstawiono proces projektowania siłowników zbudowanych z materiałów z pamięcia kształtu z zastosowaniem metod analitycznych na przykładzie członu wykonawczego punktu Braille'a stosowanego $w$ elektronicznych wyświetlaczach alfabetu Braille'a. Materiały z pamięcia kształtu sa stosunkowo nowa grupa materiałów inteligentnych, które charakteryzuja się przebudowa struktury wewnętrznej w fazach stałych na skutek zewnętrznego wymuszenia mechanicznego lub termicznego. Ta szczególna własność widoczna jest $w$ trzech zjawiskach: jednokierunkowego oraz dwukierunkowego efektu pamięci ksztattu oraz supersprężystości, które istotnie wptywają na zmianę wartości parametrów materiałowych oraz geometrię. W efekcie materiały z pamięcia kształtu znajduja zastosowanie jako napędy $w$ członach wykonawczych, w których skok siłownika jest funkcja jednego z wyżej wymienionych wymuszeń.

$W$ artykule przedstawiono założenia projektowe zaproponowanego rozwiązania technicznego oraz omówiono zjawisko wykorzystywane $w$ opracowanym modelu. Autorzy wyprowadzili odpowiednie zależności ilościowe dla przyjętej konfiguracji siłownika, których użycie zaprezentowano na przykładzie obliczeniowym. Poddano dyskusji charakterystyki zaproponowanej konfiguracji projektowej, z uwzględnieniem obszaru jej zastosowania.

Słowa kluczowe: materiały z pamięcia kształtu, materiały inteligentne, człon napędowy, wyświetlacz alfabetu Braille’a, konfiguracje projektowe, metody analityczne

\section{INTRODUCTION}

Many projects that are not accomplished in industry due to their high failure risk are fulfilled in research, which by definition aims to foster knowledge and innovation. Among these projects, a special place is taken by the issues connected with overcoming the barriers experienced by disabled people, where implementation of the newly acquired knowledge can bring specified benefits. The advantages of this approach are clearly visible and appreciated, which is also reflected in the popularization activities of universities or public institutions and foundations. They organize competitions and conferences that aim to encourage academics to deal with research topics and activities that could help disabled people overcome their barriers. The efficiency of the undertaken activities has been confirmed by numerous projects, with an outstanding example being the Prodromus 2014 (an automatized gait trainer). Also, international cooperation should be mentioned as in the case of Fundacja Instytut Rozwoju Regionalnego (the Polish Foundation Institute for Regional Development) supporting companies and universities from four EU countries by carrying out tablet prototype tests for blind people, BlindPAD 2014.

This paper is devoted to the design of an electronic Braille display with the application of intelligent materials (Yusaku et al. 2007, Anshul et al. 2013, Dhambarage et al. 2014). The authors make an attempt at designing the device by using shape-memory alloys (SMA). Because of the specific project requirements, which demand minimizing the dimensions of a device while maintaining a constant stroke of the actuator (Runyan 2014), the work is focused

* AGH University of Science and Technology, Faculty of Mechanical Engineering and Robotics, Department of Robotics and Mechatronics, Krakow, Poland; e-mail: jakub.bryla@agh.edu.pl, adam.martowicz@agh.edu.pl 
on the configurations of two oppositely operating coil springs. Four mathematical models of Braille actuators have already been defined, having considered different numbers of applied SMA springs and taking advantage of the characteristic phenomena observed for this group of alloys. The work focuses on a detailed description of the chosen aspects of the above-mentioned project, which leads to the specific mathematical model of a Braille actuator. The elaborated model was subjected to prototype experiments.

Section 2 of the paper describes the phenomena observed for SMA that were applied in the proposed solutions. Section 3 describes the formulas that defined the operation of the structure. An application example of the formulated approach is provided in Section 4. A discussion and concluding remarks are presented at the end, in Sections 5 and 6.

\section{SHAPE-MEMORY ALLOYS}

The characteristic ability of SMAs is related to the removal of residual deformations in solid phases by re-organizing the atoms in their crystal lattice. In the case of metal alloys (which are included in this group of intelligent materials), the process is usually thermally activated. This is known as martensitic transformation, and it causes the three characteristic phenomena taking place in the material structure, which are as follows (Teh 2008, Kuczma 2010):

- one-way memory effect,

- two-way memory effect,

- superelasticity.

\subsection{Martensitic transformation}

Martensitic transformation (MT) is characterized by changes in a material's structure from martensite to austenite in the case of heating, or from austenite to martensite when cooling. The beginning and end of the process are determined by the transformation temperatures, which can be modified by changing the composition of the alloy. Figure 1 presents an example of the percentage characteristic of the austenite contribution in an alloy, depending on temperature. The curve is approximated by the following function (Jianzuo et al. 2013):

$$
A_{\text {percent }}=\frac{1+\sin \left(\phi\left(T-T_{m}\right)\right)}{2} \cdot 100 \%
$$

The final form of Equation (1) depends on the sign of the temperature gradient. Thus, the components of Equation (1) take one of the two forms as follows:

$$
\phi= \begin{cases}\frac{\pi}{A_{f}-A_{s}} & \text { for heating } \\ \frac{\pi}{M_{s}-M_{f}} & \text { for cooling }\end{cases}
$$

$$
T_{m}= \begin{cases}\frac{A_{s}+A_{f}}{2} & \text { for heating } \\ \frac{M_{s}+M_{f}}{2} & \text { for cooling }\end{cases}
$$

where:

$T$ - the defined temperature,

$A_{s}, A_{f}$ - the temperatures for which transformation from martensite to austenite is initiated and completed, respectively,

$M_{s}, M_{f}$ - the temperatures for which transformation from austenite to martensite is started and finished, respectively.

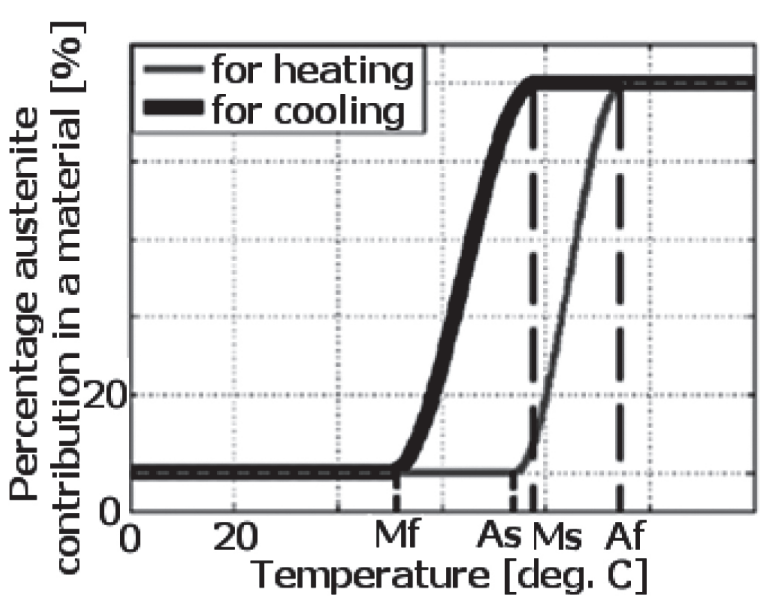

Fig. 1. Example of percentage characteristic of austenite contribution in SMA material depending on temperature

A modification of the material structure directly influences the change in the alloy material properties. When designing actuators based on SMA, the difference between the values of Young's modulus for austenite and martensite is taken into account. Based on the fact that Poisson's ratio is constant for both phases, a relationship between Kirchhoff's modulus $G$ and temperature $T$ is consequently searched.

The value of material parameter $G$ is determined based on an analysis of the percentage phase contribution 
in the material, which is described by (1). Finally, the Kirchhoff's modulus is defined by the following formula:

$$
G(T)=G_{M}+\frac{G_{A}-G_{M}}{2}\left[1+\sin \left(\phi\left(T-T_{m}\right)\right)\right]
$$

where $G_{A}$ and $G_{M}$ denote the values for austenite and martensite, respectively, and function $\phi$ is given by (2).

\subsection{One-way memory effect}

Compared to the martensitic transformation, the one-way memory effect includes an extra phase transformation taking place at low temperatures. While the force is applied to the element containing only the martensite phase (the so-called twinned martensite), this phase is first elastically deformed, and after reaching some defined stress value in the material, it subsequently turns into detwinned martensite. This happens because of the plastic deformation of the structure. After unloading the element, a recovery of the shape does not occur (which is reflected in the form of residual deformations). The original shape is obtained after performing the full cycle of the martensitic transformation. Figure 2 presents this cycle in a schematic way.

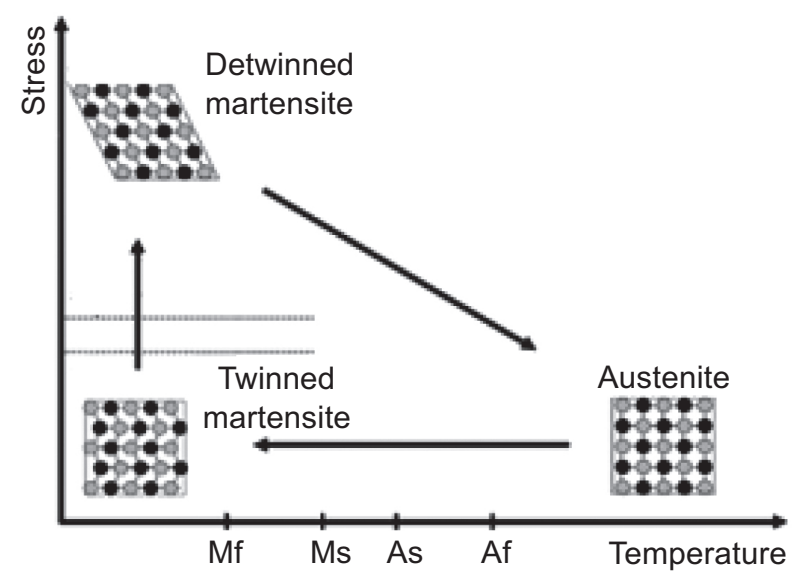

Fig. 2. Schematic representation of one-way memory effect cycle (Lagoudas 2008)

\section{DESIGN OF ACTUATOR}

As already mentioned, the basic configuration of the actuator consists of two oppositely operating coil springs. The mechanical system is presented schematically in Figure 3.

The fundamental equation that was used to formulate the mathematical description of the operation of the actuator was derived from the balance of forces. The deformed spring generates force $P$. Its value is found by the Wahl equation (Żukowski 1954); and in general, this equals:

$$
P=\frac{G \cdot d^{4}}{8 \cdot n \cdot D^{3}} \cdot \delta
$$

where:

$G$ - Kirchhoff's modulus,

$d$ - wire diameter,

$\delta$ - deflection,

$D$ - spring diameter,

$n$ - number of turns in the spring.

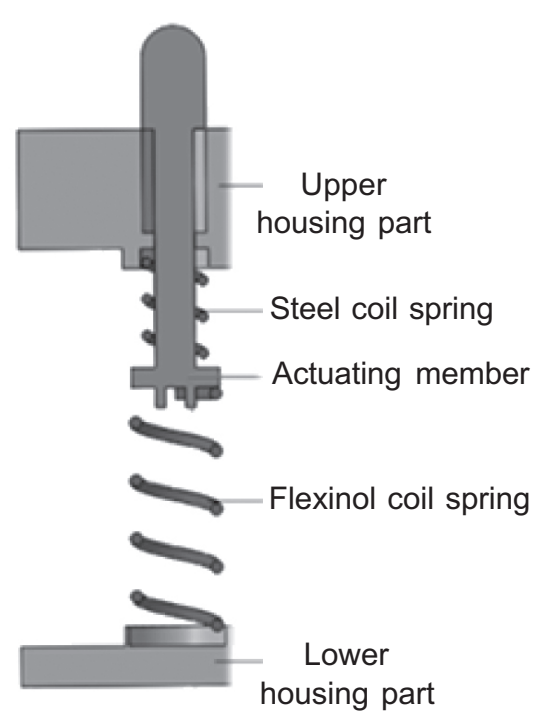

Fig. 3. Scheme of mechanical system of dot Braille actuator

The configuration of the designed actuator consists of two coil springs made of steel and SMA (Flexinol - a type of SMA material), respectively. It was assumed that the device stroke is achieved through different values of the Kirchhoff's modulus of the SMA at different temperatures, which is described by Equation (4). As a result, the position for the equilibrium point of the two cooperating springs changes. The relationship computed based on the equation of force equilibrium includes deflections of the spring components made of steel $\delta_{s}$ and SMA $\delta_{S M A}$, respectively; hence:

$$
\frac{G_{S} \cdot d_{S}^{4}}{8 \cdot n_{S} \cdot D_{S}^{3}} \cdot \delta_{S}(T)=\frac{G_{S M A}(T) \cdot d_{S M A}^{4}}{8 \cdot n_{S M A} \cdot D_{S M A}^{3}} \cdot \delta_{S M A}(T)
$$

where $\frac{G_{s} \cdot d_{s}^{4}}{8 \cdot n_{s} \cdot D_{s}^{3}}$ is the constant for the actuator connected with the steel spring characterized by the stiffness coefficient $k_{s}$, whereas the right hand side of Equation (6) describes the reaction force of the SMA spring at given 
temperature $T$. Parameters $d_{S M A}, n_{S M A}$, and $D_{S M A}$ are the geometrical parameters of the unloaded SMA spring, where: $n_{S M A}$ - number of turns in the SMA spring; $D_{S M A}-$ diameter of the SMA spring; $d_{S M A}$ - diameter of the SMA wire from which the spring is made. The changes of the diameters under load are insignificant; therefore, they are not included in equilibrium Equation (6).

The solution in the form of the actuation stroke depending on temperature $S(T)$ is defined by the following formulas:

$$
\begin{aligned}
& S(T)=\delta_{S M A}^{M}-\delta_{S M A}(T) \\
& S(T)=\delta_{S}(T)-\delta_{S}^{M}
\end{aligned}
$$

where $\delta_{S M A}^{M}$ and $\delta_{S}^{M}$ are the deflections of the SMA and steel springs, respectively, at low temperatures (when only the martensite phase exists).

The above equations are based on the geometrical relationships related to the structure presented in Figure 3. The relationships presented above are kept valid only when the inner height of the device housing is smaller than the sum of the lengths of both unloaded springs. In this case, the springs are pre-stressed, which is necessary for the proper operation of the designed actuator. Hence, the deflection of both springs is known according to equilibrium Equation (6). The linear dependence of the steel spring force vs. deflection is used to link the equation of force equilibrium (6) with Equation (8). Accordingly, Equation (8) is multiplied by the stiffness factor of steel:

$$
\begin{aligned}
& \frac{G_{S} \cdot d_{s}^{4}}{8 \cdot n_{s} \cdot D_{s}^{3}} \cdot S(T)= \\
& \quad=\frac{G_{s} \cdot d_{s}^{4}}{8 \cdot n_{s} \cdot D_{s}^{3}} \cdot \delta_{s}(T)-\frac{G_{s} \cdot d_{s}^{4}}{8 \cdot n_{s} \cdot D_{s}^{3}} \cdot \delta_{s}^{M}
\end{aligned}
$$

According to the force equilibrium principle, the force components on the right side of Equation (9) can be replaced by equivalent forces generated by the SMA spring (6):

$$
\begin{aligned}
& \frac{G_{S} \cdot d_{S}^{4}}{8 \cdot n_{S} \cdot D_{S}^{3}} \cdot S(T)=\frac{G_{S M A}(T) \cdot d_{S M A}^{4}}{8 \cdot n_{S M A} \cdot D_{S M A}^{3}} \cdot \delta_{S M A}(T)+ \\
& -\frac{G_{M} \cdot d_{S M A}^{4}}{8 \cdot n_{S M A} \cdot D_{S M A}^{3}} \cdot \delta_{S M A}^{M}
\end{aligned}
$$

Next, the right side of Equation (7) is introduced into the left side of Equation (10):

$$
\begin{gathered}
\frac{G_{S} \cdot d_{S}^{4}}{8 \cdot n_{S} \cdot D_{S}^{3}} \cdot\left(\delta_{S M A}^{M}-\delta_{S M A}(T)\right)= \\
=\frac{G_{S M A}(T) \cdot d_{S M A}^{4}}{8 \cdot n_{S M A} \cdot D_{S M A}^{3}} \cdot \delta_{S M A}(T)+ \\
-\frac{G_{M} \cdot d_{S M A}^{4}}{8 \cdot n_{S M A} \cdot D_{S M A}^{3}} \cdot \delta_{S M A}^{M}
\end{gathered}
$$

The final relationship is obtained by transforming the above equation to yield an explicit relationship between deflections $\delta_{S M A}^{M}$ and $\delta_{S M A}(T)$ :

$$
\begin{aligned}
& \delta_{S M A}(T)=\delta_{S M A}^{M} \times \\
& \times \frac{G_{S} \cdot d_{S}^{4} \cdot n_{S M A} \cdot D_{S M A}^{3}+G_{M} \cdot d_{S M A}^{4} \cdot n_{S} \cdot D_{S}^{3}}{G_{S} \cdot d_{S}^{4} \cdot n_{S M A} \cdot D_{S M A}^{3}+G_{S M A}(T) \cdot d_{S M A}^{4} \cdot n_{S} \cdot D_{S}^{3}}
\end{aligned}
$$

Substituting (12) into (7) gives the actuation stroke dependent on temperature $S(T)$ :

$$
\begin{aligned}
& S(T)=\delta_{S M A}^{M} \times \\
& \times\left(1-\frac{G_{S} \cdot d_{S}^{4} \cdot n_{S M A} \cdot D_{S M A}^{3}+G_{M} \cdot d_{S M A}^{4} \cdot n_{S} \cdot D_{S}^{3}}{G_{S} \cdot d_{S}^{4} \cdot n_{S M A} \cdot D_{S M A}^{3}+G_{S M A}(T) \cdot d_{S M A}^{4} \cdot n_{S} \cdot D_{S}^{3}}\right)
\end{aligned}
$$

The value of $\delta_{S M A}^{M}$ is computed from Equation (5), based on the known material parameters of the springs at low temperatures, equation of force equilibrium (6), and device dimensions. Note that:

$$
\delta_{S M A}(T)+\delta_{S}(T)=\text { const }
$$

where the constant value depends on both the inner height of the system housing and height of the springs.

Verification of the model was performed by analyzing the following limiting cases:

$$
G_{S M A}(T)=G_{M}
$$

This situation takes place when the model exhibits a low temperature; i.e., $T<M_{f}$. Then, the fraction in Equation (11) is equal to 1 and $\delta_{S M A}(T)=\delta_{S M A}^{M}$, which is true for the defined constraint. Furthermore, the actuator stroke is equal to 0 as found by Equation (13). 


\section{$G_{S M A}(T) \rightarrow \infty$}

The limit of function (12) for the defined $G_{S M A}$ boundary condition is 0 . This means that, if the stiffness of the SMA spring goes to infinity, then the spring deflection approaches zero. Finally, the actuator stroke would be equal to $\delta_{S M A}^{M}$, according to Equation (13).

The above considerations verify the correctness of the mathematical model. Substituting $G_{S M A}(T)=G_{A}$ in Equation (13) gives the maximum actuator stroke that is accessible for the actuator. Relationship (13) can be significantly simplified by the assumption that both the SMA and steel springs have the same geometrical parameters. In this case, Equation (13) takes the following form:

$$
S(T)=\delta_{S M A}^{M} \cdot\left(1-\frac{G_{S}+G_{M}}{G_{S}+G_{S M A}(T)}\right)
$$

\section{EXAMPLE OF SMA BASED ACTUATOR}

The above-presented designing process for SMA actuators allows one to construct a Braille dot actuator. Hereafter in the present section, an example of the calculations for the assumed springs geometry as well as the material properties is presented and discussed. From the functionality point of view, the critical properties of the device being designed are the stroke and required volume; mainly, the overall device's height. The general requirements that have to be satisfied for a Braille dot actuator are presented in Figure 4.

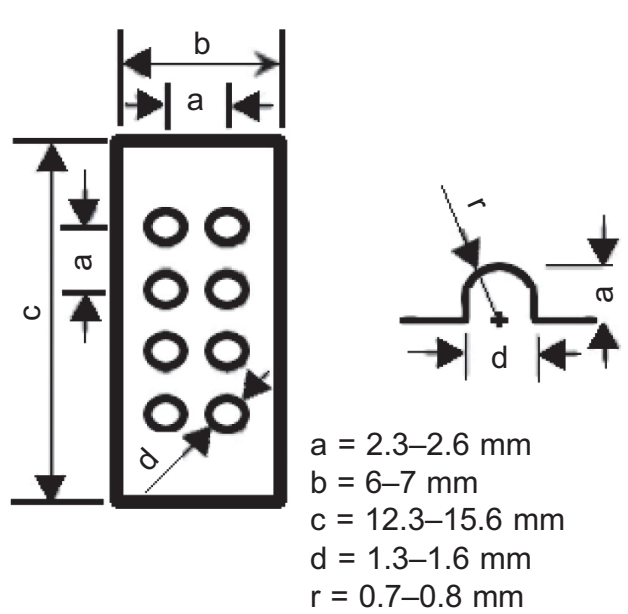

Fig. 4. Geometric restriction for Braille characters (Anshul et al. 2013)

One of the construction assumptions is that the spring that operates oppositely to the SMA component is made of steel. The value of Kirchhoff's modulus for steel equals $110 \mathrm{GPa}$, and was assumed based on the standard DIN EN 10270-1. On the other hand, Kirchhoff's modulus of SMA respectively equals $18 \mathrm{GPa}$ for the austenite phase (Churchill, Show 2008) and 7 GPa for martensite (Holschuh et al. 2014). Due to the existing significant difference between the material parameters for steel and SMA, one cannot use springs with the same geometric properties. Therefore, during the design of the actuator, the more complex form of the stroke equation was used; i.e., Equation (13) instead of (15). The proposed form of the equilibrium equation has many unknown variables, which makes the problem solution not a trivial task to perform. Hence, a genetic algorithm was used to find the final configuration. The details of the optimization algorithm used are considered to be outside the scope of the present work. Below, the results for the final configuration are shown. The parameters of the steel spring are: $D_{s}=1.8 \mathrm{~mm}, d_{s}=0.2 \mathrm{~mm}, n_{s}=20.5$, and $L_{s}=13.3 \mathrm{~mm}$, while the SMA spring is characterized by: $D_{S M A}=2.2 \mathrm{~mm}$, $d_{S M A}=0.31 \mathrm{~mm}, n_{S M A}=58$, and $L_{S M A}=43.4 \mathrm{~mm}$. Parameters $L_{S}$ and $L_{S M A}$ are, respectively, the heights of the unloaded springs. The inner height of device housing $H$ is equal to $31 \mathrm{~mm}$.

To determine the stroke of the actuator under a given temperature change, one must calculate the deflection of the SMA spring at low temperatures; i.e., below $M_{f}$. This parameter is calculated based on the following geometrical and force relationships:

$$
\begin{aligned}
& \left(L_{s}-\delta_{s}^{M}\right)+\left(L_{S M A}-\delta_{S M A}^{M}\right)=H \\
& \frac{G_{s} \cdot d_{s}^{4}}{8 \cdot n_{s} \cdot D_{s}^{3}} \cdot \delta_{S}^{M}=\frac{G_{M} \cdot d_{S M A}^{4}}{8 \cdot n_{S M A} \cdot D_{S M A}^{3}} \cdot \delta_{S M A}^{M}
\end{aligned}
$$

Based on Equations (16) and (17), the SMA spring deflection at low temperatures is $23.7 \mathrm{~mm}$ for the proposed design configuration. The calculated value can now be substituted into Equation (13), with all the necessary geometric parameters. Parameter $G_{S M A}(T)$ is calculated using Equation (4). The obtained characteristics for the device stroke under temperature change for the SMA spring are presented in Figure 5.

The obtained maximum stroke of the device, as well as the geometric parameters of the springs, satisfy the requirements shown in Figure 4. 


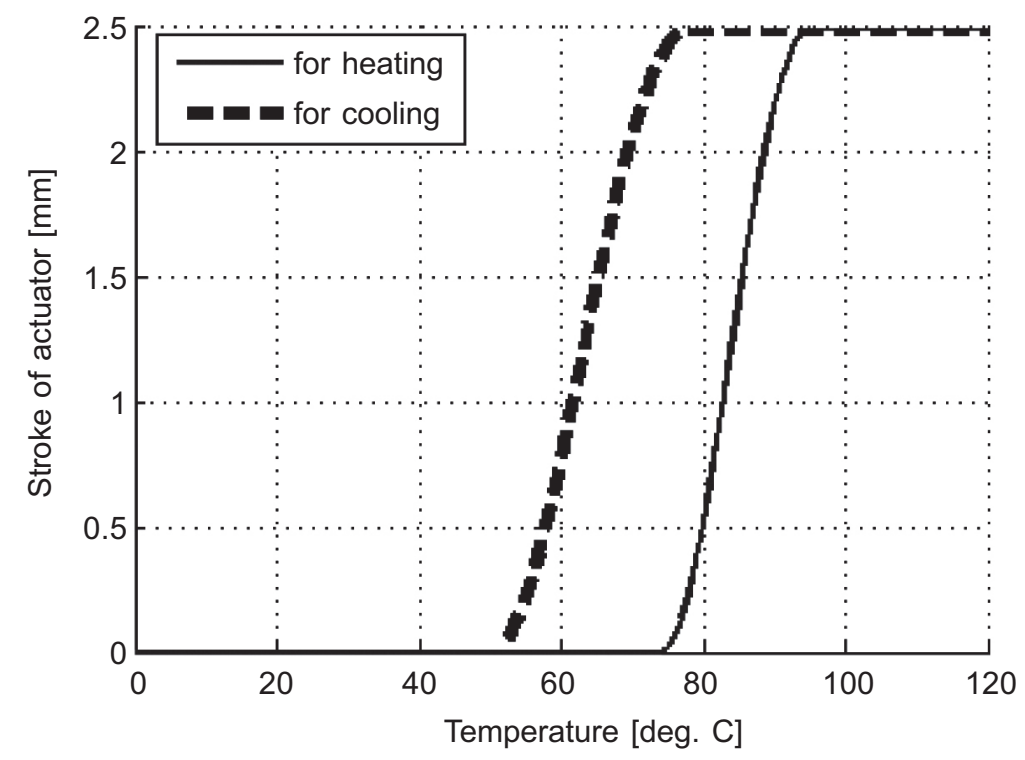

Fig. 5. Stroke for designed SMA based actuator for assumed temperature range

\section{DISCUSSION}

In the model discussed, Equation (13) provides accurate solutions when $T<M_{f}$ or $T>>A_{f}$ (Figure 1 as a reference). This applies because of the non-uniform distribution of the stress in the spring and, consequently, the effect of superelasticity. Eventually, the derived relationship allows one to determine the stroke of the actuator for only the two limiting states of the mechanical system. The solution can be extended to include a general case by adding the relationship between the change of the internal structure of the spring and its internal stress to Equation (13).

The difficulties related to the determination of the stress field of the more complex geometry of the device elements speak in favor of abandoning the formulation of a mathematical model using the analytical approach. Thus, further work should involve defining the constitutive laws for the SMA, which will be used for searching for optimal or suboptimal solutions by applying the Finite Element Method, which refers to the authors' ongoing complementary work.

\section{CONCLUDING REMARKS}

This paper has described a model of actuators based on the phenomenon present in SMA. The characteristic feature of this type of devices is controlling actuator deflection $\delta$ by the temperature of the component made of SMA.
An explicit relationship has been derived between the input and output design parameters; that is, the temperature of the SMA component and the actuator stroke (i.e., Equation (13)). This configuration refers to the cases where the temperature change is the result of the processes that occur in the system. A disadvantage of this approach is the necessity of applying air conditioning when a significant number of actuators are installed in a small area.

In the case of an electronic Braille display, heating the spring made of SMA is performed by Joule's heat on a given resistance. Consequently, applying the above-mentioned configuration of the actuator in the device would result in high energy losses, especially when maintaining the maximum actuator stroke. For this reason, the recommended solution for the Braille display is another construction of the actuator that is based on a one-way memory effect. In this case, the process of spring heating is active only when changing the actuator state, which significantly decreases the energy consumption and eliminates the necessity of applying air conditioning. Unfortunately, the mathematical description of the proposed model cannot be handled by analytical calculations. The complex geometric nature of the coil springs causes the generation of a non-trivial stress field (even under uniaxial load), which negates the possibility of using the discussed approach.

Summarizing the significance of the work, the paper presents an actuator that can be applied in various cases defined by design requirements. The quantitative relationships derived and described in this work allow to 
determine the maximum stroke of the designed dot Braille actuator and approximated trajectory between the extreme positions.

\section{Acknowledgments}

This work has been supported by the AGH University of Science and Technology, WIMiR, research grant no. 11.11.130.560.

\section{References}

Anshul S., Pranay J., Piyush C., Dhruv J., Rohan P., Balakrishnan, Rao P.V.M., 2013, Application of Shape Memory Alloy (SMA) Based Actuation for Refreshable Display of Braille. Proceedings of the ASME 2013 International Design Engineering Technical Conferences \& Computers and Information in Engineering Conference, Portland, OR, USA, 4-7.08.2013, vol. 4, 1-8.

Churchill C., Shaw J., 2008, Shakedown response of conditioned Shape Memory Alloy wire. Behavior and Mechanics of Multifunctional and Composite Material 6926, 4-5.
Dhambarage R., Wijayarathne S., Weerakkody D., Samaraweera P., Mac Donald B., Blazie D., 2014, Braille to Go Smartphone. An open-source hardware and software platform for the visually impaired and the blind. National Braille Press, Boston, MA, USA.

Holschuh B., Obropta E., Newman D., 2014, Low Spring Index NiTi Coil Actuators for Use in Active Compression Garments. IEEE/ASME Transactions on Mechatronics, 20, 1-14.

Jianzuo M., Haolei H., Jin H., 2013, Characteristics analysis and testing of SMA spring actuator. Advances in Materials Science and Engineering, 20(3), 1-7.

Kuczma M., 2010, Podstawy mechaniki konstrukcji z pamięcią ksztattu: modelowanie $i$ numeryka. Oficyna Wydawnicza Uniwersytetu Zielonogórskiego, Zielona Góra.

Lagoudas D. (ed.), 2008, Shape Memory Alloys, Modeling and Engineering Applications. Springer, Texas.

Runyan N., 2014, EAP Braille Display Needs and Requirements. National Braille Press, Boston, MA, USA.

Teh Y., 2008, Fast, accurate force and position control of shape memory alloy actuators. PhD thesis, Dept. Information Engineering, The Australian National University.

Yusaku K., Tsuyoshi S., Makoto T., Masao D., Kinji A., Takayasu S., Takao S., 2007, Sheet-type Braille displays by integrating organic field-effect transistors and polymeric actuators. IEEE Transactions Electron Devices, 54(2), 202-209.

Żukowski S., 1954, Sprężyny. Państwowe Wydawnictwa Techniczne, Warszawa. 